\title{
Methods of Water Retention in Urban Landscape
}

\author{
Metody zadržování vody v urbánní krajině
}

Nina Ličková

Ústav urbanismu, Fakulta architektury, Vysoké učení technické v Brně, Česká republika xalickova@stud.fa.vutbr.cz

\begin{abstract}
Cities are now a big burden for the landscape, also from the perspective of water management. They are not self-sufficient and take resources from the environment, while producing an excessive volume of wastewater of unsuitable biological and chemical composition.

The problems with the wastage of water resources are growing. Today we know a lot of solutions for retaining rainwater in urban landscape, saving water and maintaining the quality of water. They influence the urban planning of cities and villages. These approaches are reflected in the architecture of buildings too. The functionality and design options of these resolutions are the subject of this paper.
\end{abstract}

KEYWORDS: rainwater; retention; accumulation; purification

\begin{abstract}
ABSTRAKT: Sídla v současné době představují velkou zátěž pro krajinu, a to i z vodohospodářského pohledu. Nejsou vůbec soběstačná a čerpají zdroje z okolí. Zároveň v nevhodné míře produkují odpadní vody s nevhodným biologickým i chemickým složením. Problémy s plýtváním vodními zdroji, nevhodným využíváním vod a jejich znečištováním bez následného přečištění či recyklace se stupňují. Soudobá opatření k zadržování vody v krajině, její úspoře a zajištění její kvality se propisují do územních plánů měst a obcí, ale také zasahují do architektury staveb města. Jejich funkčnost a možnosti ztvárnění jsou předmětem této práce.
\end{abstract}

KLÍČOVÁ SLOVA: deštová voda; retence; akumulace; přečištění 


\section{Úvod}

Urbanizovaná území měst a obcí svou rozlohou znamenají významné zásahy do krajiny. Výrazně ovlivňují nejen samotné prostředí svého intravilánu, ale také velkou část okolní krajiny. Z vodohospodářského hlediska se dá říci, že ovlivňují celé povodí, ve kterém se nacházejí. Podle charakteru krajiny, svažitosti terénu, typu půd a podloží a způsobu a kvality udržování okolní krajiny se také chová povodí a vodní tok samotný. Deště přinášejí do krajiny vláhu, která musí být někam svedena, není-li schopna všechna vsáknout do půdy. Zbytkovou vodu z krajiny tedy pojme spádový vodní tok. V urbanizovaném území je však situace citelně jiná - naprostou většinu spadlé deštové vody je nucen vodní tok (s pomocí městské kanalizace) odvést pryč. Intenzita toku se tak velmi rychle stupňuje a narůstá na dimenzi a síle.

Tyto důsledky lze minimalizovat opatřeními ve městech a v obcích. Neznamená to protipovodňové zábrany v podobě vysokých zdí - ty jsou pochybením minulých desetiletí, kdy se neřešil problém prř́činy, ale řešil se jen důsledek. Aby se př̀edešlo následkům přivalů, je třeba zabývat se především eliminací odvodu srážkových vod do kanalizace a možnostmi jejich zadržení v místě spadu.

V současnosti již ukládá tuto úlohu všem stavebníkům i česká legislativa. Hospodařením s deštovými vodami se dle českých zákonů a vyhlášek musí zabývat všichni stavebníci. Města a obce především. Odvody srážkových vod ze silnic, z veřejných prostranství a ze střech veřejných budov a jednotná kanalizace - to jsou témata, která je nutno řešit. ${ }^{1}$

\section{Bilance měst a obcí}

Oproti přírodní krajině se z urbanizovaných sídel do vodních toků odvádí 55 \% spadu srážek. Vsakování spadlých srážek ve větší míře zabraňuje vysoký podíl nepropustných ploch.

Úkolem všech součinitelů podílejících se na tvorbě měst a obcí je rovněž likvidace deštové vody v místě spadu, od územního plánování přes vodohospodářský koncept územního celku až po detail provedení. ${ }^{2}$

\section{Možnosti měst a obcí}

Veškeré zpevněné povrchy v urbanizovaných územích lze s dnešními zkušenostmi a řešeními odvodnit v rámci decentralizovaných systémů HDV. Velkou inspirací je v tomto směru město Portland v Oregonu (USA), které leží na soutoku řek Willamette a Columbia. Město s vysokou mírou urbanizace také pocítilo důsledky nehos- 
podárného jednání, a rozhodlo se oslovit politický i zákonodárný aparát. Vytvořilo návod pro všechny obyvatele města, podle kterého by měli s deštovou vodou nakládat. Vznikl software, který pomáhá rozlišit nepropustné povrchy od propustných. Pro město je nyní mnohem snazší zpoplatnit výměru nepropustných ploch bez možnosti vsaku a retence, které jsou spádovány do kanalizace a mohou tak zahlcovat městskou kanalizační sít. ${ }^{3}$

Tato opatření města Portland jsou docela odlišná od české legislativy. V České republice je stanoven poplatek za odvod srážkových vod do recipientu. ${ }^{4}$ Kromě tohoto poplatku jsou platné předpisy, které obecně stanoví způsob nakládání s deštovými vodami. Jedná se o vyhlášku Ministerstva místního rozvoje č. 501/2006 Sb., o obecných požadavcích na využívání území, která stanoví pouze priority použitých řešení. Jejich správné použití posuzuje až stavební úřad. ${ }^{5}$

O hospodaření s deštovými vodami (dále jen HDV) obecně hovoří zákon o vodách č. 254/2001 Sb. ${ }^{6}$ Nejpodrobněji se HDV zabývá norma TNV 759011 Hospodaření se srážkovými vodami, která nabízí možnosti systému HDV a k němu podrobné návody. ${ }^{7}$

Vyhovět požadavkům stanoveným předpisy však musí i veřejné stavby. Například veřejná prostranství jako náměstí, dále ulice, parkoviště, budovy občanské vybavenosti, budovy státní správy a jiné.

V zahraničí nalezneme celou řadu příkladů realizací fungujících a uspokojivě ztvárněných systémů HDV. Za mnohé dovolte uvést následující.

\section{Vsakovací záhon}

Vsakovací záhon má podobu mírně se svažující prohlubně osázené hustou vegetací nebo trávou. V anglické literatuře je tento záliv označován slůvkem „swale“. Jedná se o lineární záhon, podél něhož proudí dopadající deštová voda ze střech, ulic a parkovišt'. Swale může disponovat hrazením, které zaškrtí a zadrží proud. Voda je odvedena do pole záhonu, kde je vegetací zpomalena a filtrována. Následně vsakuje do půdy. Swale může zprostředkovat odtok vody do trativodu nebo vsakovacího objektu. ${ }^{8}$

\section{Zelené střechy}

Vegetační střecha dokáže zachytit a zadržet až 60 \% ročních srážek, které na ni dopadnou. Oproti klasickým rovným střechám je pořizovací cena zelených střech o něco vyšší, ale jejich životnost je téměř dvakrát delší (cca 40 let). Výhodou je estetická stránka a zlepšení kvality prostředí. Využití střešních teras k relaxaci výrazně 
zvyšuje komfort budovy. V nejvyšších patrech lze vytvořit př́ijemnou zelenou zahradu. Proto již $\mathrm{k}$ tomuto řešení přistoupila řada veřejných budov. Např́íklad chicagská radnice, kde vznikla legendární rozkvetlá pochozí střešní zahrada. ${ }^{9}$ Nebo v Brně na prrístavbě $\mathrm{k}$ Nemocnici Milosrdných bratř́í, kde vznikla střešní terasa u bufetu. ${ }^{10}$

\section{Krytí podzemních parkovišt'}

Tématem př́buzným zeleným střechám jsou podzemní parkoviště a jejich pochozí a pojezdné stropy. Ve městech se stupňují požadavky na parkovací místa, nejlépe situovaná v centrech v co nejvyšším počtu. Hledají se způsoby jejich začlenění do městského organizmu, aniž by nepř́íznivě ovlivnila estetiku vnitřních prostor měst. Kapacitní podzemní parkoviště mohou být situována pod parkovými plochami, jako je tomu například před Janáčkovým divadlem v Brně. ${ }^{11}$

\section{Ozeleněné vsakovací nádrže}

Upravené prohlubně, které mohou být vyhloubené nebo obehnané opěrnými stěnami zachycujícími okolní terén. $\mathrm{Z}$ nepropustných ploch jsou srážkové vody potrubím přiváděny do rezervoáru, kde dochází $\mathrm{k}$ retenci - tedy dočasnému zadržení vody. Odtud voda postupně vsakuje do země. Vody mohou být svedeny např́iklad ze střech rozsáhlých objektů, silnic nebo parkovišt'.

Tyto nádrže bezpečně zachycují menší prrívalové deště. Tento systém bývá používán i u přehrad a jezů ke korekci průtoku a k jeho případnému zadržení. Nádrže lze dimenzovat i na velké prŕvaly v oblastech, kde je velmi dobrá propustnost zeminy. Tyto nádrže jsou vhodné do zákoutí měst a obcí, kde je požadavek na př́ijemné vlhkostní klima. $^{12}$

\section{Vsakovací květináče}

Hmotné kontejnery na rostliny s otevřeným dnem umožňují pomalé vsakování srážkové vody do zeminy. Fungují jako retenční nádrže. Po dešti se naplní vodou a dočasně drží hladinu, která postupně klesá podle toho, jak voda pomalu vsakuje do zeminy.

Vsakovací kontejnery na rostliny lze vyrobit v různých velikostech a tvarech z kamene, betonu, cihel, plastu, ale i ze dřeva. Tento systém vsakování je vhodný pouze pro oblasti s propustnými zeminami v prostorově omezených situacích. ${ }^{13}$

\section{Propustný povrch}

Byl vyvinut nový druh pochozího a pojezdného povrchu chodníků a komunikací, 
který umožňuje, aby se do spodních vrstev vsakovala spadlá voda z celé plochy. Je vyroben z propustného asfaltu nebo propustného betonu s vysokou mírou mezer mezi částicemi. Oba materiály se podobají konvenčnímu asfaltu a betonu, ale ve svém objemu obsahují více skulin, aby voda mohla pronikat skrz chodník nebo komunikaci do lože z drceného kameniva a pak vsakovat do zeminy. Pro únosnost při stejném zatížení bývá vrstva propustného asfaltu zpravidla silnější než vrstva tradičního betonu. Propustný asfalt se skládá $\mathrm{z}$ hrubého kameniva a asfaltových pojiv s hrubší strukturou. Voda prosakuje skrz malé dutiny ponechané ve finální vrstvě asfaltu. Silná vrstva štěrku pod asfaltem umožňuje rychlý průtok vody skrz souvrství do podloží. Vizuálně se propustný asfalt velmi podobá konvenčnímu asfaltu, i když má znatelně hrubší povrch. Od vzhledu je odvozen společný název „popcorn mix“. Speciální prostupná betonová směs se skládá z portlandského cementu, tř́iděného hrubého kameniva a vody.

Vedle novodobých povrchů popsaných výše však stále existuje celá řada zatravňovacích dlažeb a koberců s bohatou tvarovou škálou vzorů. ${ }^{14}$

\section{Závěr}

V současnosti se objevuje celá řada pokrokových řešení a př́stupů, které jsou velkým přínosem z hlediska estetiky a zlepšení kvality prostředí měst a obcí, ale především po stránce vodohospodářské. Systémy HDV zvyšují retenční schopnost urbánní krajiny a nabízí možnost vodu jímat a využívat. To je velká kapitola, na kterou v rámci hledání cest k udržitelnému rozvoji nesmíme zapomenout.

PŘIROZENÉ POVODÍ (ZALESNĚNÉ)

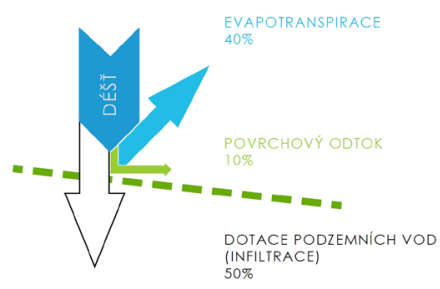

URBANIZOVANÉ POVODÍ

(75-100\% NEPROPUSTNÝCH PLOCH)

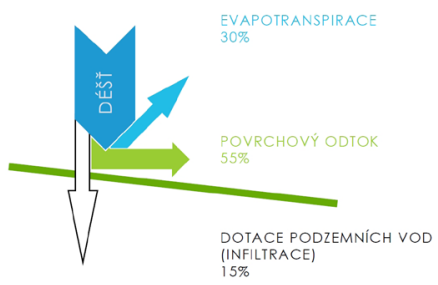

Obr. 1.: Porovnání přirozeného a urbanizovaného povodí 




Obr. 2.: Schematický nákres vsakovacího záhonu

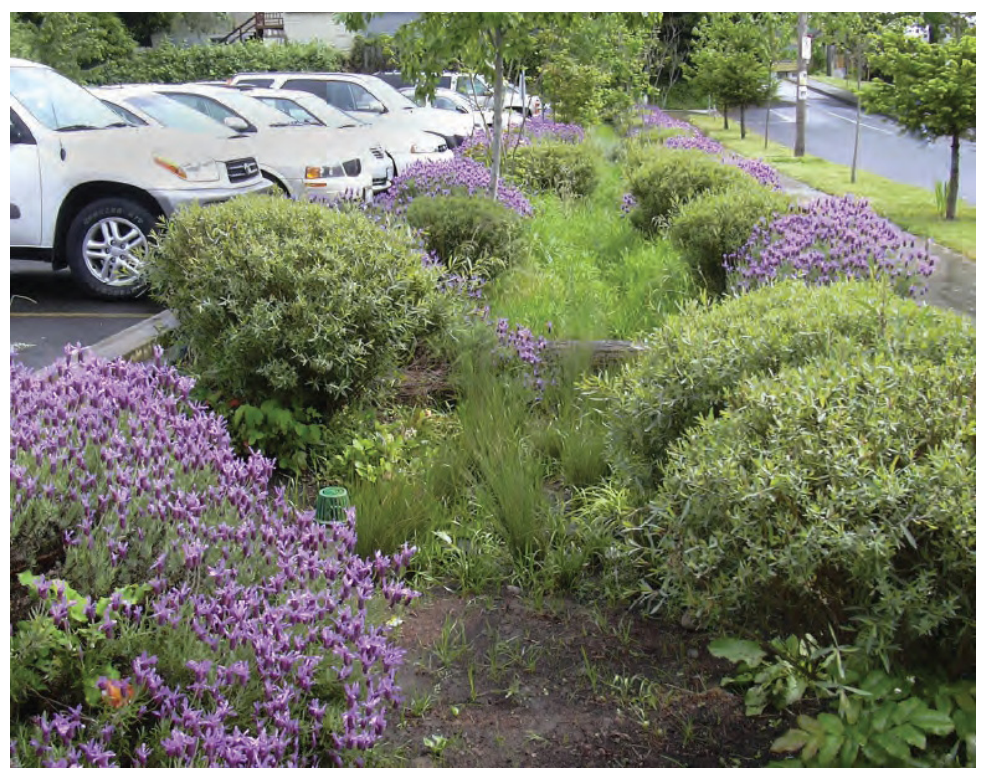

Obr. 3.: Fotografie vsakovacího záhonu 


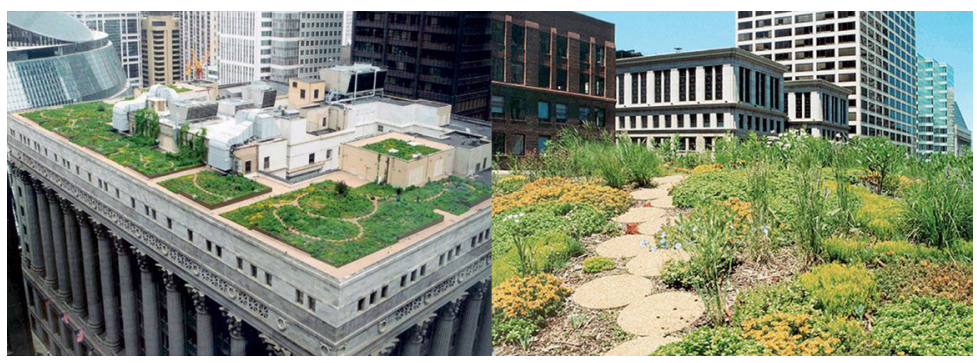

Obr. 4.: Střecha Chicagské radnice s bohatým porostem vegetace

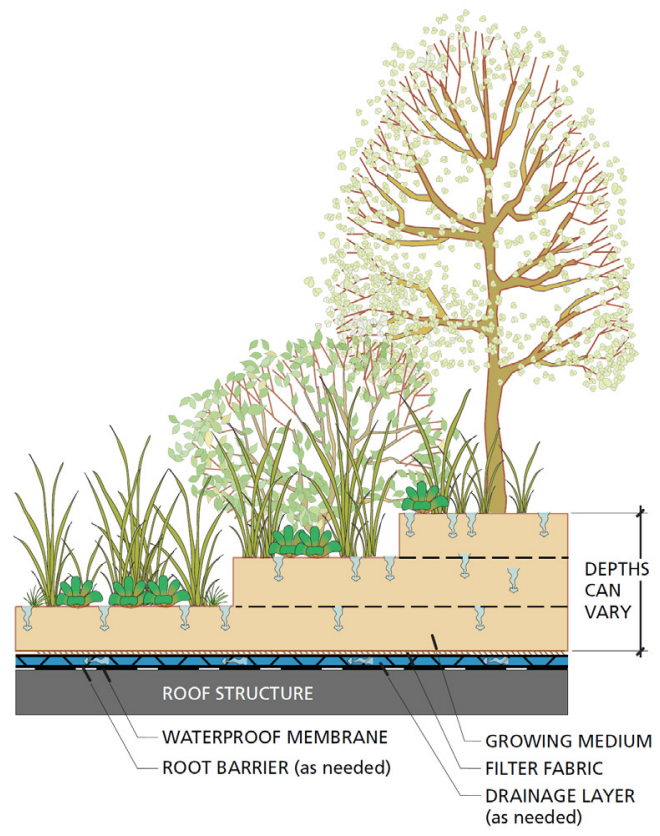

Obr. 5.: Schematický průřrez vegetační střechou 


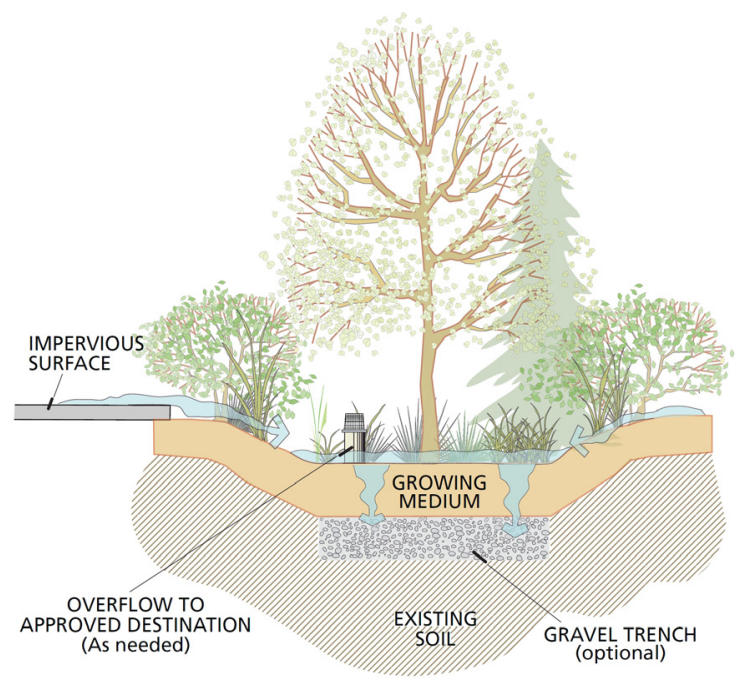

Obr. 6.: Schematický nákres vegetační vsakovací nádrže



Obr. 7.: Fotografie vegetační vsakovací nádrže 


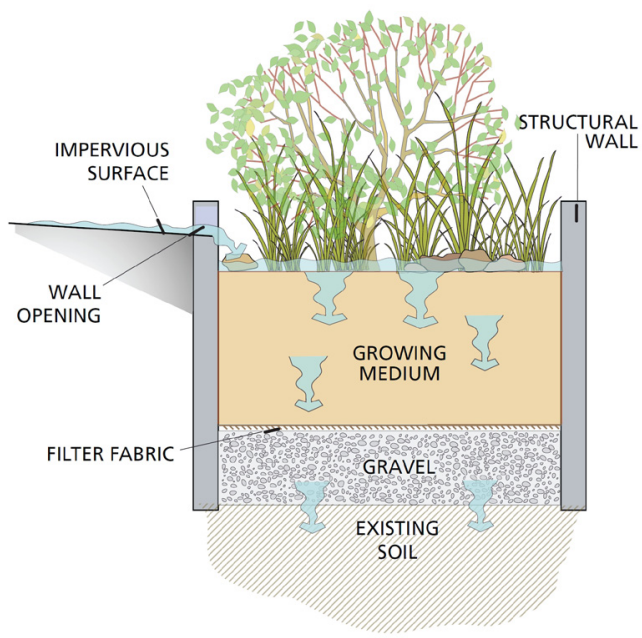

Obr. 8.: Schematický nákres vsakovacího kontejneru

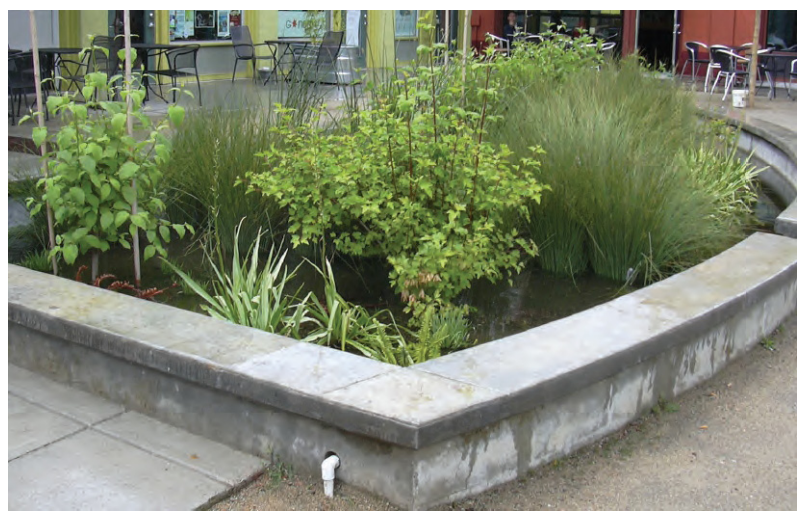

Obr. 9.: Fotografie vsakovacího kontejneru

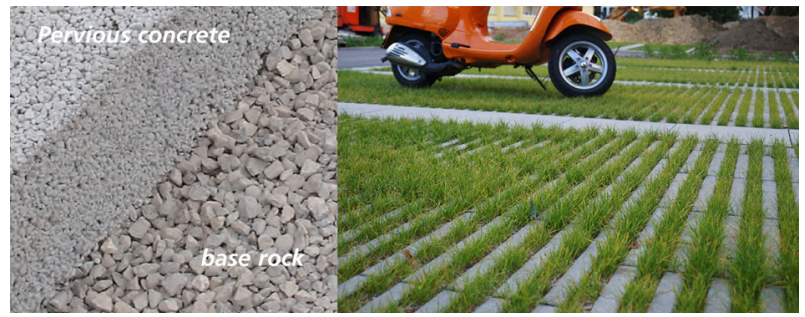

Obr. 10.: Vodě-propustný beton, Zatravňovací dlažby 


\section{Poznámky:}

1. KREJČÍ, Vladimír. Odvodnění urbanizovaných území - koncepční přístup. Brno: Noel 2000, 2003. ISBN 80-86020-39-8.

2. VÍTEK, Jiří, David STRÁNSKÝ, Ivana KABELKOVÁ, Vojtěch BAREŠ a Radim VÍTEK. Hospodaření s deštovou vodou v ČR. Praha: 01/71 ZO ČSOP Koniklec, 2015. ISBN 978-80-260-7815-9.

3. Historical methods of stormwater management billing for Portland customers [online]. Portland, Oregon [cit. 2016-07-30]. Dostupné z: https://www.portlandoregon.gov/bes/article/561489

4. pozn.: je tak uvedeno ne Vyhlášce č. 428/2001 Sb. Ministerstva zemědělství ze dne 16. listopadu 2001, způsob výpočtu množství srážkových vod, odváděných do kanalizace bez měření, se provádí podle $\$ 31$ Vyhlášky č. 428/2001 Sb.

5. ČR. Vyhláška 501/2006, Sb. O obecných požadavcích na využívání území. In: 501/2006. 2006, ročník 2006, číslo 501. Dostupné také z: http://www.mmr.cz/cs/ Ministerstvo/Ministerstvo/Legislativa-v-priprave/Platne-pravni-predpisy/Oblast-uzemniho-planovani-a-stavebniho-radu

6. ČR. Zákon č. 254/2001 Sb., o vodách. In: 254/2001. 2001, ročník 2001, číslo 254. Dostupné také z: http://www.mmr.cz/cs/Ministerstvo/Ministerstvo/Legislativa-v-priprave/Platne-pravni-predpisy/Oblast-uzemniho-planovani-a-stavebniho-radu

7. ČR. Hospodaření se srážkovými vodami (HDV) - TNV 75 9011, odvětvová technická norma vodního hospodářství, ročník 2013. Dostupné také z: https:// docs.google.com/viewer?docex=1\&url=http://eagri.cz/public/web/file/209372/ TNV_75_9011__brezen_2013.pdf

8. VEGETATED SWALES: Stormwater Solutions. Library. Environmental Services: working for clean rivers [online]. (C) 2015 City of Portland, Oregon. [cit. 2016-0730]. Dostupné z: http://www.portlandoregon.gov/bes/31870

9. How The Chicago City Hall Green Roof is Greening the Concrete Jungle. [online]. Poslední verze 2011 [cit. 2015-11-11]. Dostupné na World Wide Web: < http:// landarchs.com/how-the-chicago-city-hall-green-roof-is-greening-the-concrete-jungle/>, autor fotografií: Mark Farina

10. pozn.: Pavilon akutní medicíny nemocnice Milosrdných bratří, Autor: Architektonická kancelář Burian - Křivinka, více viz http://www.archiweb.cz/buildings. php?action $=$ show\&id $=695$

11. ECOROOFS: Stormwater Solutions. Library. Environmental Services: working for clean rivers [online]. (c) 2015 City of Portland, Oregon. [cit. 2016-07-30]. Dostupné z: http://www.portlandoregon.gov/bes/31870

12. VEGETATED INFILTRATION BASINS: rain gardens. Environmental Services: working for clean rivers [online]. 2006 [cit. 2016-07-30]. Dostupné z: http://www. portlandoregon.gov/bes/31002 
13. INFILTRATION PLANTERS: rain gardens. Environmental Services: working for clean rivers. Stormwater Solutions [online]. 2006 [cit. 2016-07-30]. Dostupné z: http://www.portlandoregon.gov/bes/31870

14. PERVIOUS PAVEMENT: rain gardens. Environmental Services: working for clean rivers. Stormwater Solutions [online]. 2006 [cit. 2016-07-30]. Dostupné z: http://www.portlandoregon.gov/bes/31870

\section{Prameny}

ČR. Hospodaření se srážkovými vodami (HDV) - TNV 75 9011, odvětvová technická norma vodního hospodářství, ročník 2013. Dostupné také z: https:// docs.google.com/viewer?docex=1\&url=http://eagri.cz/public/web/file/209372/ TNV_75_9011__brezen_2013.pdf

ČR. Vyhláška 501/2006, Sb. O obecných požadavcích na využívání území. In: 501/2006. 2006, ročník 2006, číslo 501. Dostupné také z: http://www.mmr.cz/cs/ Ministerstvo/Ministerstvo/Legislativa-v-priprave/Platne-pravni-predpisy/Oblast-uzemniho-planovani-a-stavebniho-radu

ČR. Zákon č. 254/2001 Sb., o vodách. In: 254/2001. 2001, ročník 2001, číslo 254. Dostupné také z: http://www.mmr.cz/cs/Ministerstvo/Ministerstvo/Legislativa-v-priprave/Platne-pravni-predpisy/Oblast-uzemniho-planovani-a-stavebniho-radu

ECOROOFS: Stormwater Solutions. Library. Environmental Services: working for clean rivers [online]. (C) 2015 City of Portland, Oregon. [cit. 2016-07-30]. Dostupné z: http://www.portlandoregon.gov/bes/31870

Historical methods of stormwater management billing for Portland customers [online]. Portland, Oregon [cit. 2016-07-30]. Dostupné z: https://www.portlandoregon.gov/bes/article/561489

How The Chicago City Hall Green Roof is Greening the Concrete Jungle. [online]. Poslední verze 2011 [cit. 2015-11-11]. Dostupné na World Wide Web: < http:// landarchs.com/how-the-chicago-city-hall-green-roof-is-greening-the-concrete-jungle/>, autor fotografií: Mark Farina

INFILTRATION PLANTERS: rain gardens. Environmental Services: working for clean rivers. Stormwater Solutions [online]. 2006 [cit. 2016-07-30]. Dostupné z: http://www.portlandoregon.gov/bes/31870

KREJČÍ, Vladimír. Odvodnění urbanizovaných území - koncepční přístup. Brno: Noel 2000, 2003. ISBN 80-86020-39-8.

PERVIOUS PAVEMENT: rain gardens. Environmental Services: working for clean rivers. Stormwater Solutions [online]. 2006 [cit. 2016-07-30]. Dostupné z: http:// www.portlandoregon.gov/bes/31870

VEGETATED INFILTRATION BASINS: rain gardens. Environmental Services: working for clean rivers [online]. 2006 [cit. 2016-07-30]. Dostupné z: http://www. portlandoregon.gov/bes/31002 
VEGETATED SWALES: Stormwater Solutions. Library. Environmental Services: working for clean rivers [online]. ( 2015 City of Portland, Oregon. [cit. 2016-0730]. Dostupné z: http://www.portlandoregon.gov/bes/31870

VÍTEK, Jiř́, David STRÁNSKÝ, Ivana KABELKOVÁ, Vojtěch BAREŠ a Radim VÍTEK. Hospodaření s deštovou vodouv ČR. Praha: 01/71 ZO ČSOP Koniklec, 2015. ISBN 978-80-260-7815-9.

\section{Seznam vyobrazení}

Obr. 1.: VÍTEK, Jiří, David STRÁNSKÝ, Ivana KABELKOVÁ, Vojtěch BAREŠ a Radim VÍTEK. Hospodaření s deštovou vodou v ČR. Praha: 01/71 ZO ČSOP Koniklec, 2015. ISBN 978-80-260-7815-9.

Obr. 2.: VEGETATED SWALES: Stormwater Solutions. Library. Environmental Services: working for clean rivers [online]. () 2015 City of Portland, Oregon. [cit. 2016-07-30]. Dostupné z: http://www.portlandoregon.gov/bes/31870

Obr. 3.: VEGETATED SWALES: Stormwater Solutions. Library. Environmental Services: working for clean rivers [online]. () 2015 City of Portland, Oregon. [cit. 2016-07-30]. Dostupné z: http://www.portlandoregon.gov/bes/31870

Obr. 4.: How The Chicago City Hall Green Roof is Greening the Concrete Jungle. [online]. Poslední verze 2011 [cit. 2015-11-11]. Dostupné na World Wide Web: $<$ http://landarchs.com/how-the-chicago-city-hall-green-roof-is-greening-the-concrete-jungle/>, autor fotografií: Mark Farina

Obr. 5.: ECOROOFS: Stormwater Solutions. Library. Environmental Services: working for clean rivers [online]. (c) 2015 City of Portland, Oregon. [cit. 2016-07-30]. Dostupné z: http://www.portlandoregon.gov/bes/31870

Obr. 6.: VEGETATED INFILTRATION BASINS: rain gardens. Environmental Services: working for clean rivers [online]. 2006 [cit. 2016-07-30]. Dostupné z: http:// www.portlandoregon.gov/bes/31002

Obr. 7.: VEGETATED INFILTRATION BASINS: rain gardens. Environmental Services: working for clean rivers [online]. 2006 [cit. 2016-07-30]. Dostupné z: http:// www.portlandoregon.gov/bes/31002

Obr. 8.: INFILTRATION PLANTERS: rain gardens. Environmental Services: working for clean rivers. Stormwater Solutions [online]. 2006 [cit. 2016-07-30]. Dostupné z: http://www.portlandoregon.gov/bes/31870

Obr. 9.: INFILTRATION PLANTERS: rain gardens. Environmental Services: working for clean rivers. Stormwater Solutions [online]. 2006 [cit. 2016-07-30]. Dostupné z: http://www.portlandoregon.gov/bes/31870

Obr. 10.: PERVIOUS PAVEMENT: rain gardens. Environmental Services: working for clean rivers. Stormwater Solutions [online]. 2006 [cit. 2016-07-30]. Dostupné z: http://www.portlandoregon.gov/bes/31870, Ekologické dlažby. Bydleni IQ [online]. (๑) 2014 Bydleni IQ, 2013 [cit. 2016-08-02]. Dostupné z: http://www.bydleni-iq.cz/temata/materialy-a-technologie/ekologicke-dlazby/ 